Article

\title{
The Truth behind the Brexit Vote: Clearing away Illusion after Two Years of Confusion
}

\author{
Sae Won Chung ${ }^{1}$ and Yongmin Kim ${ }^{2, *}$ \\ 1 Graduate School of International Studies, Korea University, Seoul 02841, Korea; swchung37@korea.ac.kr \\ 2 KU China Institute, Konkuk University, Seoul 05029, Korea \\ * Correspondence: kym7224@naver.com; Tel.: +82-2-450-3384
}

Received: 8 August 2019; Accepted: 18 September 2019; Published: 23 September 2019

\begin{abstract}
Since the referendum in 2016, Brexit has become the most controversial conundrum in the UK. This study aimed to revisit this issue by focusing on the communicative patterns of Brexit-related parties (the Conservatives, Labour, and UK Independence Party). Firstly, it attempted to provide the conceptual backgrounds of Brexit by explaining its development process from Cameron's pledge of an in/out referendum to the present. Subsequently, it reviewed empirical studies on Brexit in diverse areas of social science. Most empirical studies point out that British political practitioners' perceptions about Brexit were the root cause, but they were not able to provide an overview of these perceptions. The novelty of this study lies in examining the patterns of these perceptions by focusing on communicative framings embedded in the posts created in their official Facebook pages from the date of the referendum to that of the Brexit withdrawal agreement. To extract these framings, this study adopted an automated semantic network analysis geared by NodeXL—software for data collection and visualisation. The results show that these parties emphasised that they were the only legitimate political party to solve the Brexit crisis without providing concrete solutions or measures. These parties' ill-founded communications endanger sustainable social media communications and interactions in the UK. Hence, it is vital to establish a more reliable fact-checking information-sharing system between the political elite and the general public.
\end{abstract}

Keywords: Brexit; semantic network analysis; framing; political communication; social media; British politics

\section{Introduction}

On 23 June 2016, the EU membership referendum (Brexit) revealed unexpected results, and on 25 November 2018, 27 EU member countries approved the motion. Since then, British politics have become chaotic in every aspect; from the worst-case scenario of a "no-deal Brexit" (wherein the UK's departure from the European Union on 29 March 2019, has now been moved to 31 October 2019) to second referendum petitions; several different opinions have been exchanged due to the varied information that was provided to the British public during the 2016 Brexit referendum.

This research aimed to discover which information British political agents provided to the British public can be considered misleading (which ultimately created confusion). This study used framing theory as its methodology, and it considered how the unexpected results of Brexit came to be and examined which aspects accepted by the voters' major parties were for the sake of promoting their own aims (i.e., to "remain" or for "Brexit"). Additionally, this research determined the reasons why the political parties' promises were not fulfilled, causing the current confusion. Finally, this study examined the causes of framing and identified which stereotypes caused the Brexit vote behaviours, ultimately discovering that most Brexit supporters' goals were not achievable while also revealing which information was most influential on voters. 
This study obtained information regarding Brexit from the official Facebook pages of the Conservative, Labour, and UK Independence (UKIP) parties. Just after the Brexit referendum, British researchers published a report that analysed the dynamics of the British media, voters, and campaigns. In these reports, Brexit camp members used social media more actively in their referendum campaign than did those who rejected the movement [1]. According to the Office for National Statistics, $89 \%$ of British adults use the internet, or nine out of 10 British households have access to the internet via mobile phones, laptops, tablets, or handheld devices [2]. Among these devices, smartphones are used by $72 \%$ of British adults [2]; therefore, the Brexit camp actively engaged in a high percentage of internet usage among the British people by utilising social network services for promotion. In fact, according to Figure 1, British voters stated that, of the social network service platforms, they mostly used Facebook or YouTube.

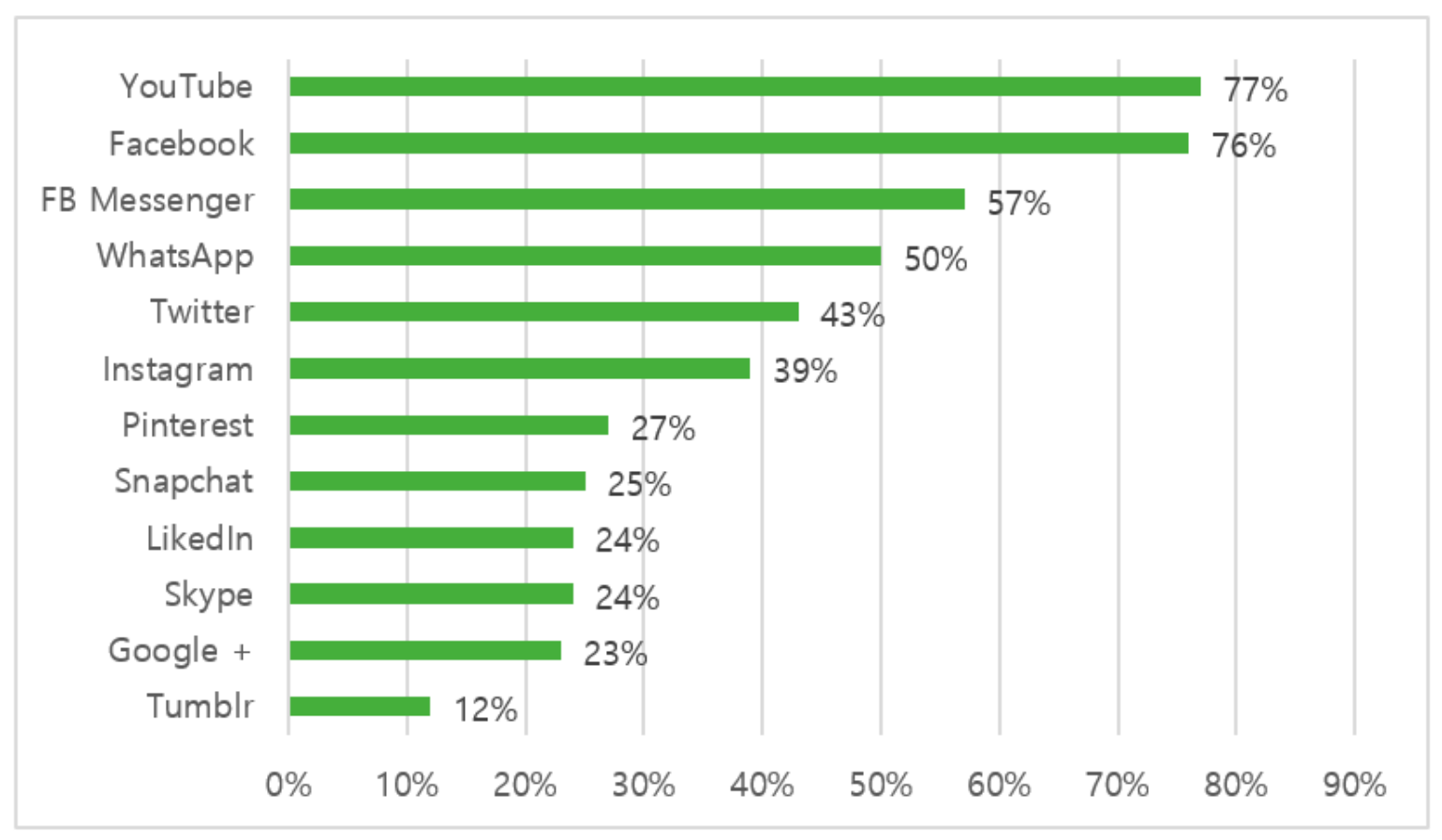

Figure 1. The most active social media platforms in the UK [3].

\section{Conceptual Background}

\subsection{Brexit: Development and Process}

In order to recall what was stated by both the "remain" and "leave" campaigns at the time of the referendum, it is vital to understand the background of Brexit and its negotiation process. Identifying the change in framing from 2016 to 2018 in Britain is fundamental to this research. Based on warnings from the financial market, the major political parties hoped that risk aversion would convince British voters to remain in the EU; however, $52 \%$ of British voters ultimately were in favour of leaving the EU, a sentiment that was mainly caused by strong Euroscepticism, particularly in England. This vote also revealed that people cared more about immigration and national sovereignty than about the negative economic effect of leaving the single market of the EU. It also indicated that voters did not fully understand the impact this would have on their daily lives. According to the voting results map, every major region in Britain voted to leave the EU, with the exceptions of London, Scotland, and Northern Ireland; notably, the working and middle classes particularly supported the idea of leaving the EU.

One of the primary reasons that the referendum lost the vote was due to the framing "mistakes" made by the campaign that wanted to remain in the EU, which originated in 2013. Former Prime 
Minister David Cameron originally pledged to hold the Brexit referendum in 2017 to satisfy the Eurosceptics inside his own Conservative Party and to win the general election in 2015. It was from a continuing trend of Euroscepticism throughout the 2014 European elections that UKIP claimed a dramatic victory in the UK, a record in their party's history. The Conservatives wanted to regain their initiative in British politics by fusing populism and Euroscepticism [4]. The Tories were concerned about being overtaken in national polls, thus they needed stronger and more concrete measures for maximising their impact on the UK [4]. After the 2015 election, the Conservative Party became the majority party in the House of Commons [5]. The second main reason that the "remain" campaign lost the vote was because they attempted to persuade the British public on the basis of economic anxieties and resentments. Ironically, this caused political anger that fuelled the ultimate vote to leave the EU. Finally, the third reason why this campaign lost the vote was because they kept a negative campaign going during the referendum period. They only identified the negative aspects of the economy, border control, and National Health Service (NHS) funding. They maintained an attitude that leaving the EU would create negative results, but they could not provide enough positive reasons to remain in the EU. Instead, the camp should have admitted that the EU had many problems that needed to be addressed if Britain stayed in the EU while arguing that Britain would be a lot worse off outside of the EU.

The winning campaign pulled off a surprising victory by making three main promises to the British public [6]. First, they promised to return NHS "the £350 M the EU takes every week" [6] (Paragraph 3). This promise was central to the campaign and was painted on the side of one of their buses that toured Britain; however, it was the first promise that they broke after the referendum took place. Both Nigel Farage (the UKIP leader at the time) and Iain Duncan Smith (part of the "leave" vote) denied saying that the NHS would get $£ 350 \mathrm{M}$ a week; instead, they stated that it was a mistake made by other leave campaigners despite the fact that they used the slogan on an official campaign bus as a symbol of the leave vote [6]. This mistake comes out of a misunderstanding regarding the rebate between the EU and the UK [7]. Considering the rebate from the EU, the UK actually paid closer to $£ 250 \mathrm{M}$ a week.

The second key promise made by the "leave" camp was that a vote for leaving the EU would be a vote to reduce immigration. When immigration in Britain reached a near-record 333,000 immigrants on 26 May 2016, Boris Johnson stated that the situation was completely uncontrollable [8]. Coupled with the UKIP's "breaking point" poster featuring Syrian refugees, it was not surprising that many voters believed that the leave campaign was promising deep cuts in immigration. This promise led to one of the most effective campaign advertisements in the Brexit referendum [9]. Ultimately, however, the leave campaign reported that they did not promise any particular target figure for reducing immigration but rather a general goal of fewer than 100,000 immigrants. After two years, the Northern Ireland border issue came to light, revealing that the leave camp could not keep its promise of restricting net migration to below 100,000 people [10]. This figure was completely unachievable whether Britain exited or remained in the EU.

The third key promise made by the leave camp was that five million more migrants could enter Britain by 2030 if Turkey (with a population of 78 million) and four other applicant countries joined the EU. This referred back to the EU's response to the migration crisis, in which the EU extended a "free-for-all" invitation to Macedonia, Montenegro, Serbia, Albania, and Turkey to join the EU [8]. The leave campaign did not withdraw this claim until after the referendum took place and even highlighted the claim on its final campaign leaflet, which also implied that staying in the EU would open the door to Syrian and Iraqi migration. This claim possibly amplified immigration fears among the British public. This claim, however, was quite misleading, as Turkey has still not been able to join the EU.

In summary, all three key promises that the leave camp made in 2016 have been either broken or deemed false, which demonstrates that the framing used in 2016 was misleading; however, this framing worked well enough to hand the leave camp a Brexit victory. This study, then, aimed to investigate how the three major British political parties (the Conservatives, Labour Party, and UKIP) framed and 
delivered information to the British public not only leading up to the Brexit referendum (23 June 2016) but also until EU leaders approved the Brexit deal (25 November 2018). This examination reveals a change in public opinion during the Brexit negotiation process. However, the Brexit chaos was not over as of 29 March 2019; although the original time limit has expired, Britain has continued to delay the final decision on Brexit and cannot settle on any deal in the British Parliament until 2 April 2019. All that is known about the situation is that the initial "no deal" deadline has been moved to 31 October 2019. The UK participated in the 2019 European Parliament elections and Brexit negotiations are still ongoing.

\subsection{Brexit: Empirical Studies}

The 2016 referendum results invited research on the origins, consequences, and future implications of Brexit. This paper focused on the literature from several major social science disciplines, such as politics, economics, and media/communication studies.

Political scientists have covered mainly the power struggle within the Conservative Party [11] and the problems in British society's elite class [12]. They have also focused on immigration fear [13], anti-politics movements [14], and the division of class in the modern UK [15]. After reviewing the political studies on Brexit, the present authors were inclined to focus on the cleavage among the existing political parties in the UK given that the existing studies lack detailed explanations of the ideological gaps among the parties. To describe these gaps, it is important to discuss how the UK's major political parties perceive Brexit. Hence, the present study is useful because it explores party framings based on semantic networks.

In economic literature, the essential debate has revolved around Brexit's effect on the UK and the EU and on what the future will look like. Crafts [16] pointed out that the UK's EU membership has had positive effects in terms of an increase in trade and in UK productivity due to the fact of increased competition. Subsequently, Brexit would be risky, so a careful negotiation between the UK and the EU would be essential in order to reduce the risks of Brexit. Dhingra and Sampson [17] also issued an analytical report on Brexit that reviewed the advantages and drawbacks regarding the UK's uncertain future. They found that keeping the UK's political and economic sovereignty would be one of the main benefits. In exchange, losing the UK's trade income and bargaining power could be a set of drawbacks. In terms of foreign direct investment (FDI), Dhingra et al. [18] warned that the UK would face a $22 \%$ decrease in FDI over the next ten years because its EU membership positively and concretely affected the UK's FDI levels. Furthermore, Sampson [19] described a scenario in which Brexit would make the UK poorer because of a possible new barrier to trading with and migrating to the UK. Contrary to these accounts, some economic reports criticise that economic impact assessments of Brexit were rather over-predicted and exaggerated in terms of the negative impact $[20,21]$. Whether Brexit's economic effects will be positive or negative, it is still difficult to properly recognise them. These arguments merely amplify the controversy regarding Brexit. Hence, the existing economic studies illustrate that the critical elements surrounding Brexit decisions, such as an uncertain future, painful negotiations, and subsequent unexpected post-Brexit results, have been concealed and fabricated by the country's decision makers. Consequently, these opposing views on Brexit will increase confusion among the UK public.

In media and communication studies, researchers have focused on the Brexit camp's strategies for engaging the voters. Soon after the 2016 referendum, $80 \mathrm{UK}$ academics gathered to share their immediate thoughts, reflections, and early research insights to address the 2016 Brexit referendum [22]. This report consisted of small contributions from a diverse range of disciplines, including political science, cultural studies, journalism studies, and psychology. Within this report, four of eight sections were devoted to media and journalism (Section 3: News; Section 4: Journalism; Section 5: Campaign and Political Communication; and Section 7: Social Media). In Section 7, in particular, the authors of the report indicated that the leave party actively engaged the voters of the 2016 referendum using social media. For instance, the leave camp utilised Twitter to promote its campaign efforts, with a consistent 
focus on the diverse issues of Brexit—politics, domestic issues, immigration, business, trade, economy, and security $[1,23]$. The leave camp was much more successful than the remain camp at targeting voters to achieve voter registration, fundraising, intelligence gathering, and message dissemination [24]. One of the impressive examples of the Leave camp's Brexit campaign propaganda was the development of a downloadable smartphone application for promoting active two-way communication between the leave party and voters [24]. This report indicates that the political parties in the UK relied on social media to disseminate their messages to the general public to gain their support to legitimatize Brexit. After the referendum, these parties paid a significant amount of attention to social media for propagandistic purposes. In this regard, the present study paid more attention to how the UK's three major political parties delivered Brexit-related information to the general public.

Within the "leave" campaign, there were three key argument areas covered regarding the Brexit referendum-immigration, sovereignty, and the economy [25]. Later, it was pointed out that the leave and remain campaigns focused on different framing areas. The leave camp and the UKIP actively employed an immigration frame in their strategies. In their efforts, they established multiple links, such as immigration and the economy, immigration and security, and immigration and social changes [25]. This strategy worked well because it promoted the debate shift between immigration framing and sovereignty framing [25]. In contrast, the remain camp utilised a one-dimensional campaign, focusing on the economy [25]. In addition, Khabaz [26] argued that the top-selling British newspapers played a vital role in propagating Brexit messages by using repetitive frames that highlighted long-established concerns in the UK, such as "taking control", "democracy", and "sovereignty" (p. 496). These campaigns made by the majority political parties in the UK indicate that they employed elaborated framing strategies in order to gain the general public's support.

Reviewing the Brexit-related literature, the present study developed a series of insights. The political science research indicates the importance of providing a detailed account of the cleavage among the political parties. In addition, it is also important to consider public opinion. The conservative parties (e.g., the Tories and UKIP) focused on what made the British public make the surprising Brexit referendum decision. In the three years since the referendum, several explanations have been offered for why this phenomenon happened; however, all that is currently understood about the decision is that it was a very complicated, diverse political issue that did not have one singular cause. The economic studies indicate that British politicians overlooked the significance of the possible negative post-Brexit decision scenarios. The communication studies demonstrate that it is clear that British politicians approached the general public using sophisticated and multi-dimensional strategies based on framings that enabled diversifiable debates with their opponents. Based on the plethora of literature, this study individually examined how British political parties concealed the facts of Brexit by disseminating misleading information based on cognate framings.

\section{Theoretical Background and Methodology}

\subsection{Framing}

People rely on their individual framings (i.e., schema of interpretation) in order to understand new events [27]. These individual framings are influential because they can forge public ideology [28]. Arguably, the power of framing comes from its cognitive function, as framings aid the mental process of acquiring knowledge and understanding through the thinking process. Human beings are naturally cognitive "misers" who want to think less about certain issues [29]. Entman [30] defined framing as groups of ideas stored in individuals' brains that guide individuals' information processing, while Scheufele [31] suggested that framings consist of two types: global and long-term political views and short-term issue-related frames of reference.

Later, Entman [32] suggested a cascading activation model of framings, wherein individuals in each level of the cascade provide feedback to each other based on their individual framings, which is summarised in Figure 2. In his model, the administration is located at the top of the cascade, 
then, other elites—such as politicians, ex-officials, or experts—-the media, and the public are located at the subordinate levels. When the administrator delivers messages based on their individual framings to the actors in the lower levels of the cascade, those who are in the lower levels of the cascades will accept the information thereafter. At the bottom line, the actors at the lower level provide feedback to the actors at the upper levels [32].

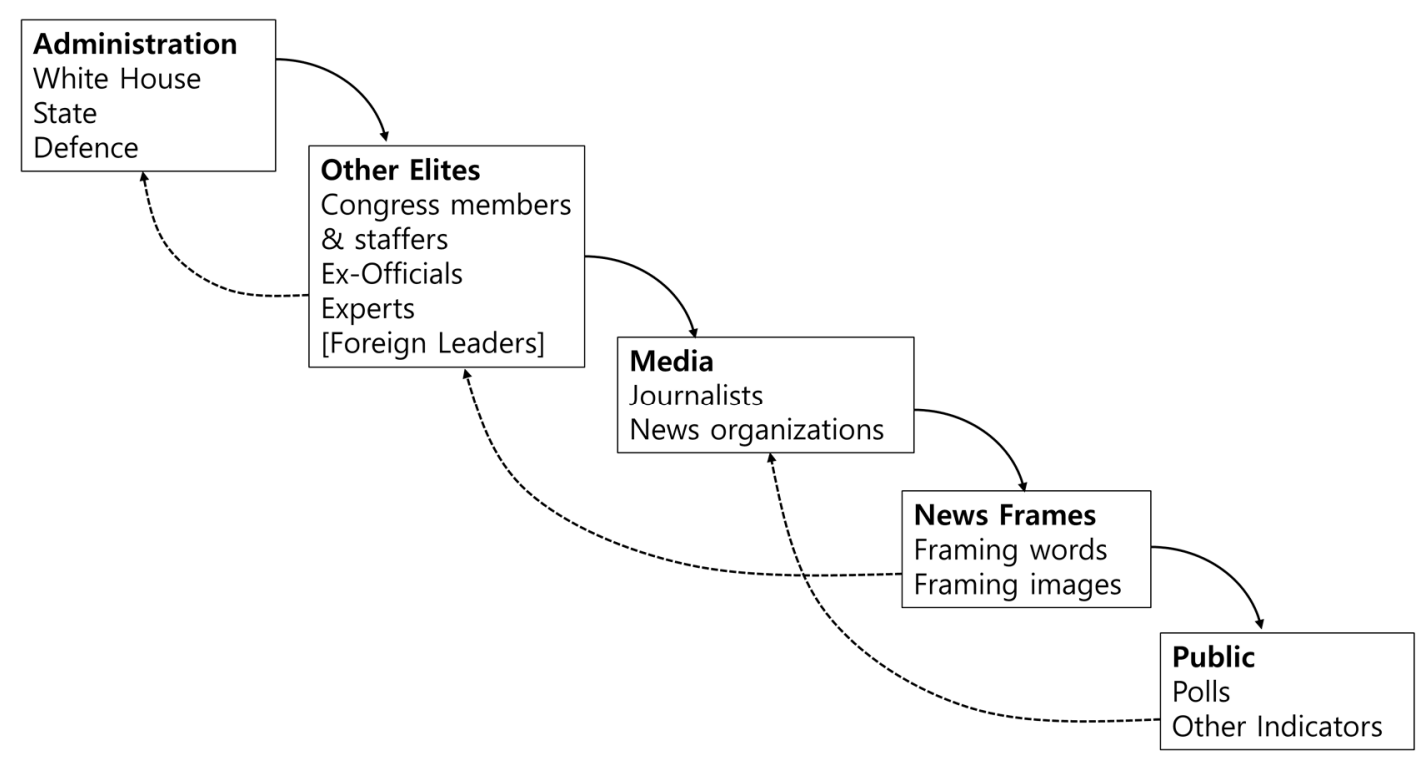

Figure 2. Entman's [32] cascading activation model of framings (p. 419).

Thanks to social media, the actors at the top level of Entman's cascading activation model (in the present study, the actors were political parties in the UK) attempted to communicate directly with the general public, the lowest level actor in the opinion cascade. This article is novel because it examines the dynamics of Brexit-related framing, which extends beyond just the media to include all aspects of British society. Furthermore, by examining the social media platforms of the three main British parties, this study illustrates the salient framings based on their messages to the general public. Hence, the current study used political science methodology to uncover this phenomenon's political meaning.

\subsection{Semantic Network Analysis}

This study employed an automated semantic network analysis, which is different from the methods used in the existing Brexit studies. The majority of framing analysis methods use qualitative analyses and manual coding. However, Matthes and Kohring described four limitations of manual coding. First, in order to perform reasonable coding, the coders need to undergo robust coding training based on sound coding books. Second, this coding practice makes the research design more complex. Third, coders have a definite, limited amount of analysable text. Fourth, it is challenging for coders to discover meaningful clusters when there are too many variables used in the coding practices [33].

To overcome the current limitations of a framing analysis based on manual coding, this study employed a semantic network analysis based on computer software. For example, van Attelveldt [34] was the first researcher to use computer software to extract associative framings using the co-occurrences from the cases of terrorism in the news. Figure 3 illustrates the whole picture of the semantic network analysis. 


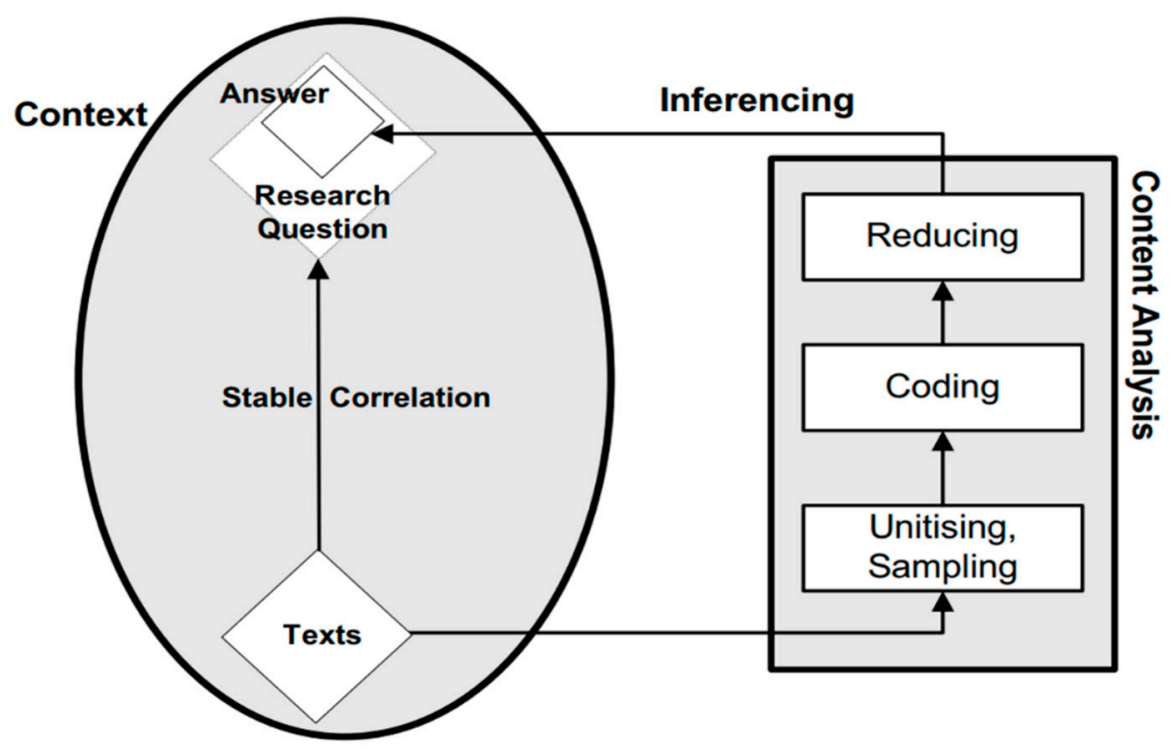

Figure 3. van Attelveldt's [34] semantic network analysis (p. 17).

Subsequently, additional scholars have successfully identified framings via automated semantic network analysis. For example, Schultz et al. [35] identified the strategic framings of the BP crises. Moreover, Jiang et al. [36] explored how the Chinese and American media have addressed international affairs by identifying distinct concepts as they corresponded with salient issues. In addition, one of the notable benefits of automated semantic network analysis is the ability to extract essential representations from a massive amount of unstructured data [37]. This mechanism is presented in Figure 4.

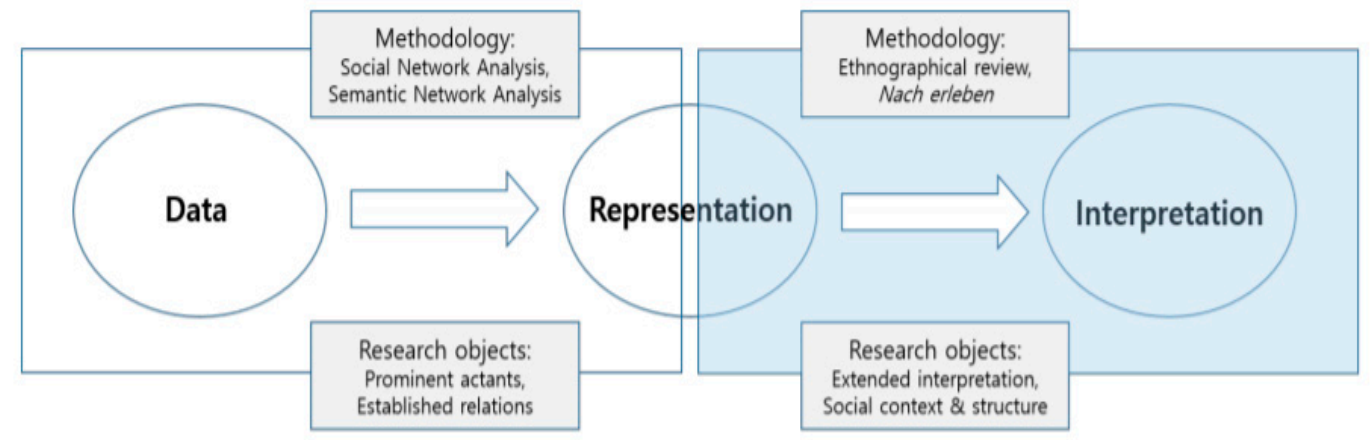

Figure 4. The role of semantic network analysis in interpretive sociology [30] (p. 11).

By using this methodology, coders can detect salient words that create repetitive framings in a more stable manner. This study used the NodeXL coding software, which enables the detection of salient words and visualises the results based on semantic network maps. A more detailed overview of the analysis process is presented in the subsequent sections.

\subsection{Research Methodology}

To measure the dynamics of Brexit-related framings, this study conducted a computer-assisted semantic network analysis that suggested semantic framings, whereas conventional framing analyses are conducted by coders' thorough reading. Matthes and Kohring suggested four problems of manual framing analysis. First, it is difficult to guarantee the quality of the analysis unless the manual coding is based on sound codebooks and robust coder training. Second, this robust training increases the complexity of manual analysis. Third, it could be inefficient because of the coders' analysis of time constraints. Fourth, when there are multiple variables to code, the analysts might not be able to find meaningful clusters or reliable narratives in the texts [33]. 
To address these challenges, researchers have attempted to validate automated framing analysis by comparing the analysis with manual coding for media frames [34]. Yoon and Chung [38] conducted a semantic network analysis of the Suwon (Korean) municipal government's Facebook page, investigating posts concerning the Suwon Hwaseong Festival to explore promotion pattern changes by presenting framing changes from 2015 to 2017. They subsequently explored media framings of conservative and liberal newspapers in South Korea concerning PyeongChang 2018 by employing a computer-aided semantic network analysis [39]. The results of these studies explicitly presented the structures of the propagating agents' perceptions, which were too abstract to be previously understood. Also, the above studies illustrated the detailed processes involved in semantic network analyses. Also, the NodeXL, which Yoon and Chung used, is an efficient tool in terms of visualising the semantic networks. Hence, Yoon and Chung's semantic network analyses can be understood as benchmarking studies for this type of methodology, and their analyses were useful for the present study.

To validate computer-aided analyses, this study employed NodeXL to extract the data from the official Facebook pages of the British Conservatives, the Labour Party, and the UKIP. Figure 5 presents the snapshots of these three parties' Facebook pages.

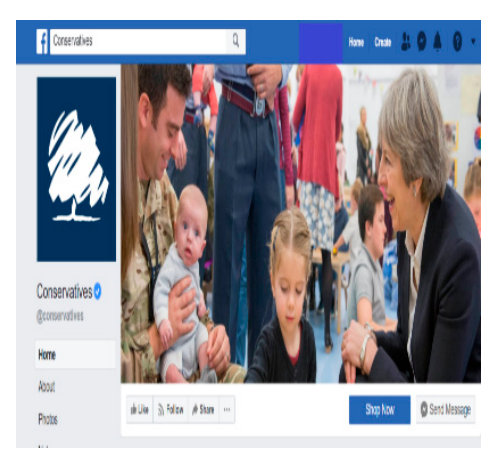

(a)

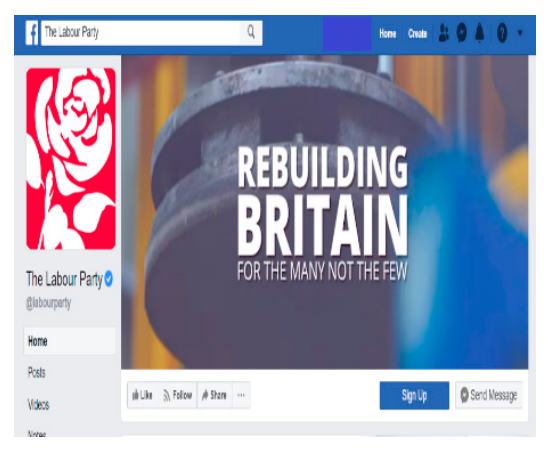

(b)

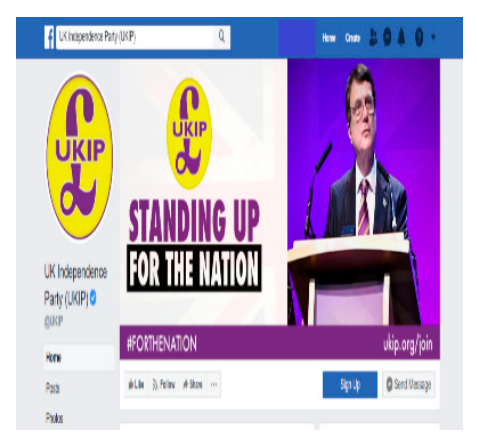

(c)

Figure 5. The official Facebook pages of the (a) Conservatives, (b) the Labour Party, and (c) the UKIP.

NodeXL is an add-in programme attached to Microsoft Excel, which enables ordinary coders to perform data collection, coding, and visualisation processes. This programme was developed by the Social Media Research Foundation, which continuously updates the analytic functions of this programme. The main features of this programme are network visualisation (e.g., visualising network graphs and setting the colour, shape, size, label, and opacity of vertices and edges), social network analysis (e.g., calculating overall network metrics such as density and modularity, basic vertex metrics such as degree, in-degree and out-degree, and group vertices by cluster or attributes), content analysis (e.g., text analysis, sentiment analysis, time series analysis, and top items, such as words, word pairs, URLs, and hashtags), and data import and export from other analytic programmes such as, GraphML, Pajek, UCINet, matrix, and MS Office [40]. In the coding process, we employed the feature called "Import from Facebook Fan Page Network" (Figure 6) to collect existing comments, posts, and replies. The data collection period included a range from the date of the Brexit referendum (23 June 2016) to the date that the Brexit deal was made (25 November 2018). 


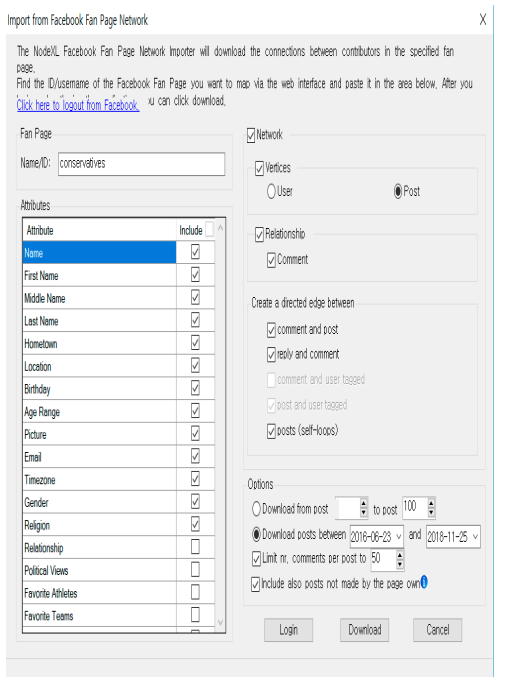

(a)

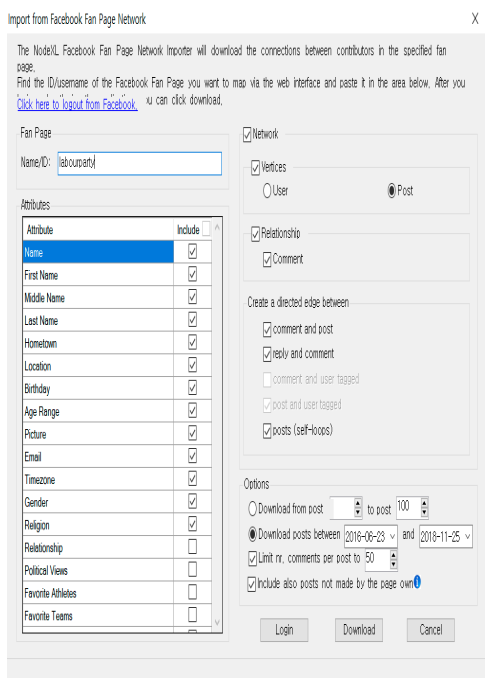

(b)

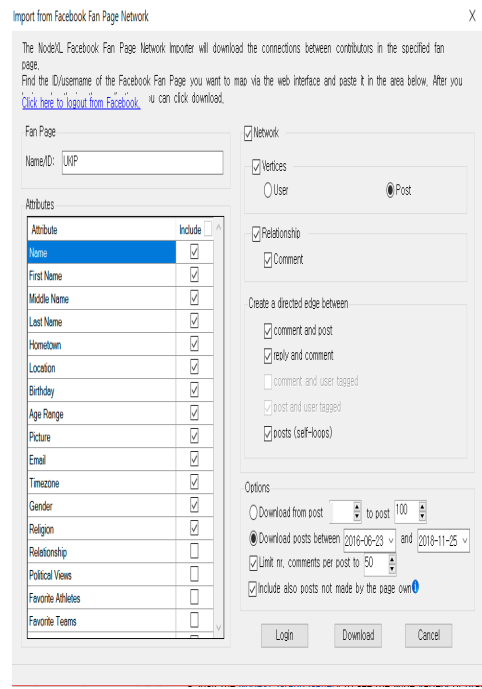

(c)

Figure 6. The data import of the Facebook pages of the (a) Conservatives, (b) the Labour Party, and (c) the UKIP.

After the data collection, we employed this programme to determine the frequently mentioned words in the collected texts and, subsequently, this programme drew semantic networks out of these words. Then, these semantic networks could be visualised using this programme. Within the visualised semantic networks, there are two main elements-vertex and edge. Vertex (a dot in the graph) refers to the keywords in collected discourses of the Facebook posts and edge (the lines between the dots) and their relationships among themselves [37]. Using "group vertices by clustering function", we were able to draw proper framings out of the semantic networks. Ultimately, after the visualisations, we can draw some interpretations in order to explain further social implications from these embedded framings within semantic networks.

\section{Results}

After the data import of the Facebook postings of these three official pages, automatic text analysis was conducted by selecting word and word pair metrics dialogue. These metrics calculated the most frequently mentioned word pairs within the postings of these Facebook pages. Based on the collected word pairings, NodeXL can create word clusters according to their semantic relatedness. Subsequently, NodeXL can visualise them in the format of semantic network maps. These results are presented in Figures 7-9. Figure 7 displays the results of the Conservatives' official Facebook page from the day of Brexit referendum (23 June 2016) to the day of Brexit deal released (25 November 2018). 


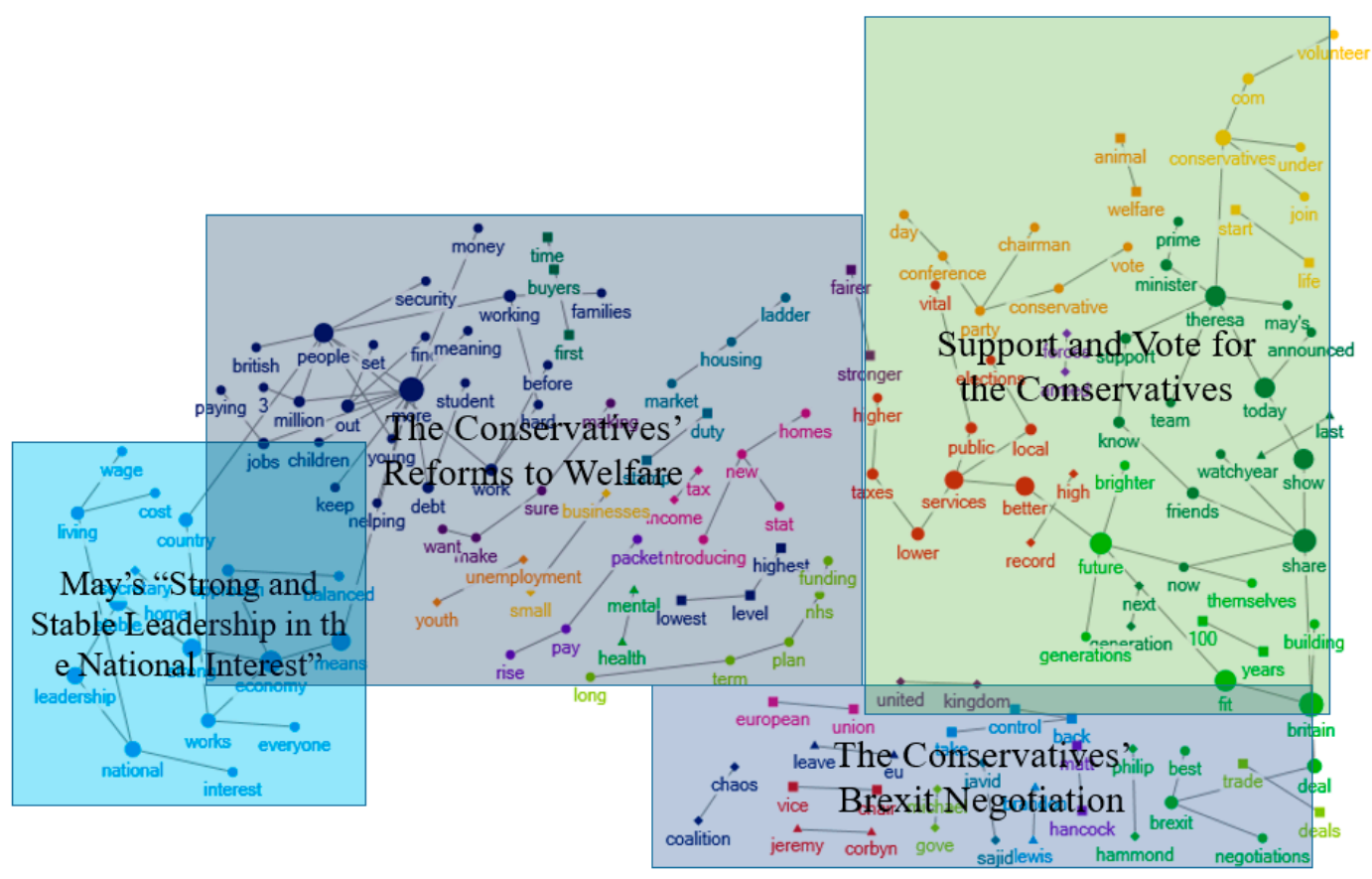

Figure 7. Semantic network with framings of the Conservatives' official Facebook page.

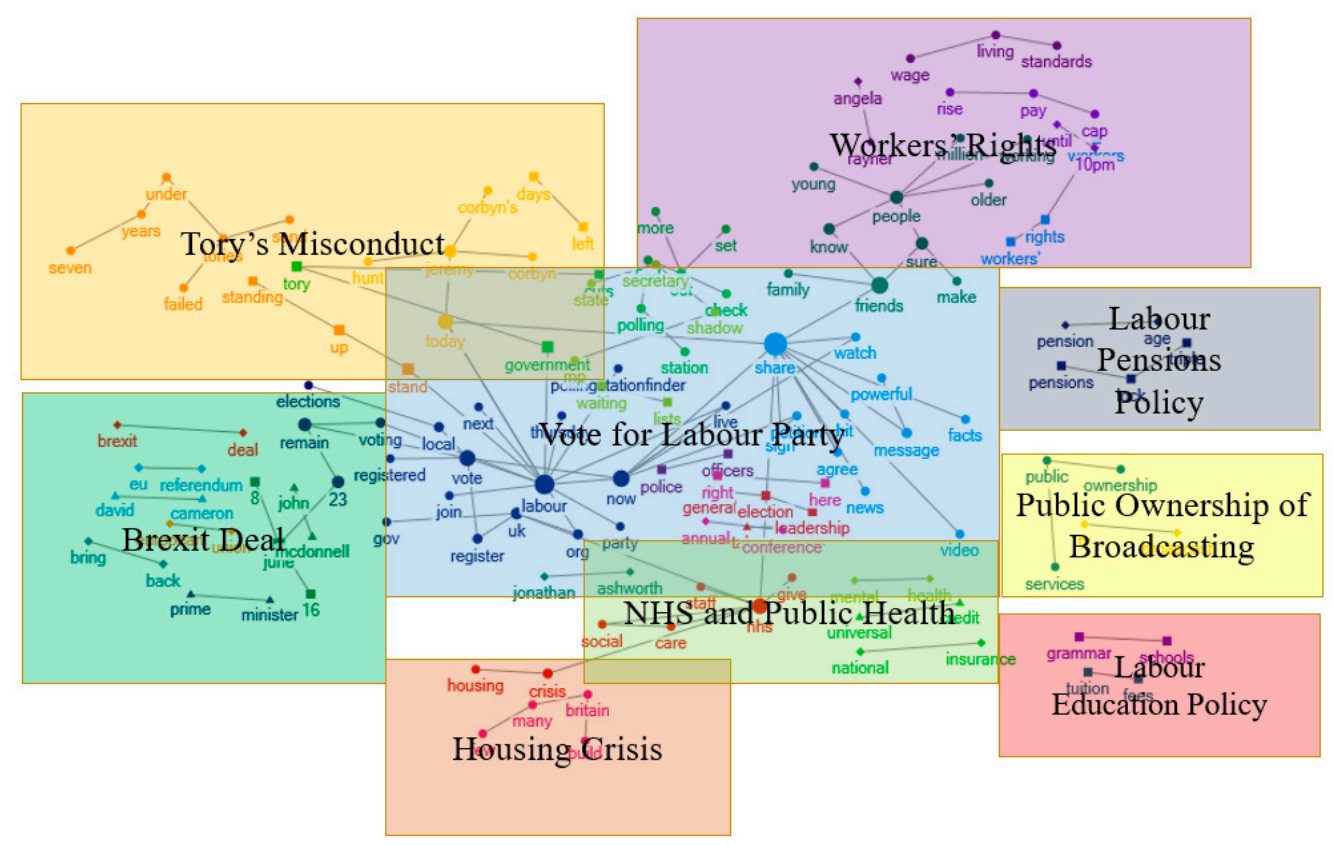

Figure 8. Semantic network with framings of the Labour Party's official Facebook page. 


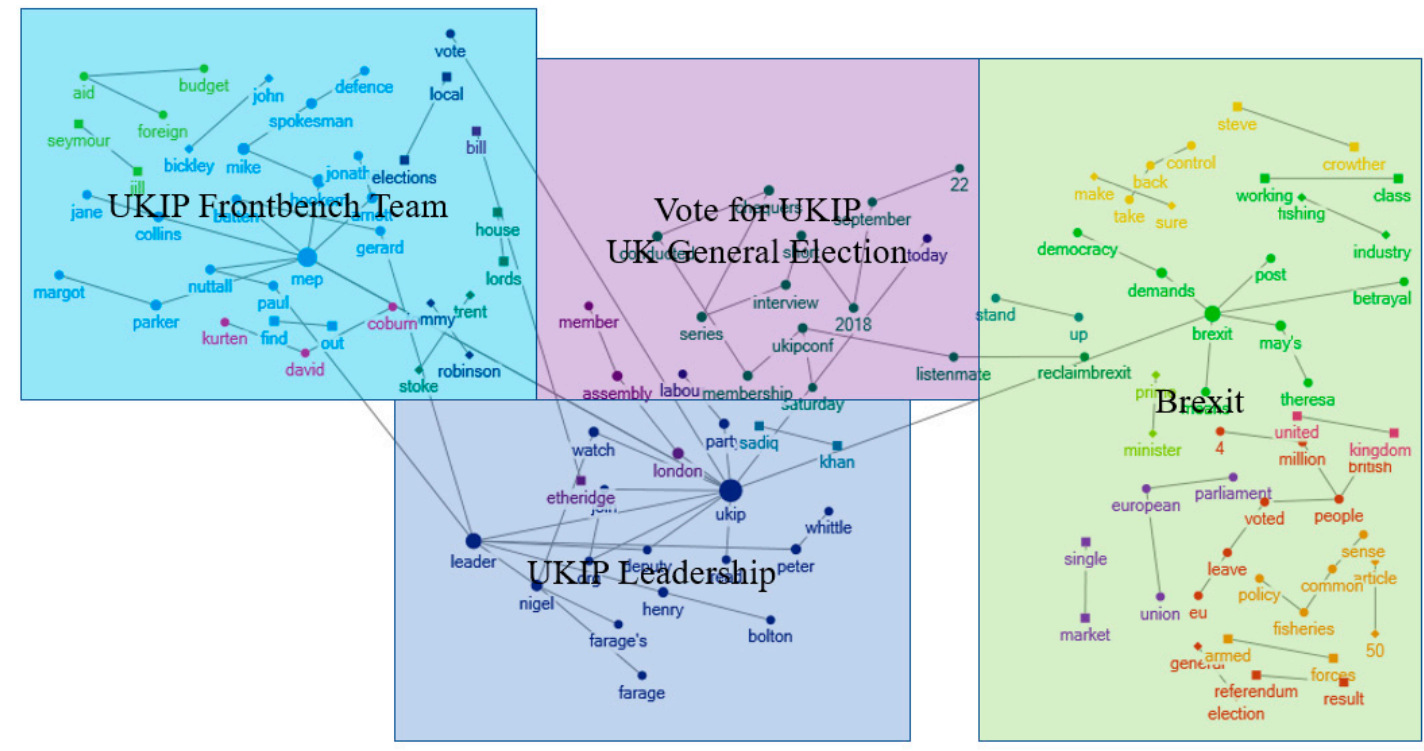

Figure 9. Semantic network with framings of the UKIP's official Facebook page.

As revealed by these results, the Conservatives claimed that Britain needed Brexit to reform the welfare system. According to this party, supporting Prime Minister May and her cabinet would give Britain strong and stable leadership by reforming the welfare policy, providing a stable NHS and enough housing, thereby promoting Britain's national interests. This, according to Conservatives, would create the best deal in the Brexit negotiation with the EU, ultimately helping British national interests and security. They warned that the Labour party (led by Jeremy Corbyn) would bring chaos to British society, emphasising that the Conservative Party was the only reliable option for negotiating with the EU. The Conservatives promoted welfare reform, a reduced financial obligation to the EU, and strengthening British border control to limit the entrance of immigrants coming to Britain for jobs. Their lack of ability to achieve these promises at the time of Brexit, however, caused the current political confusion.

In the 2017 general election, the Conservative Party promised in its manifesto to leave the single market and customs union while seeking a "deep and special partnership" [41] with the EU and securing a "smooth and orderly Brexit" [41]. The party also stated at this time that "no deal is better than a bad deal for the UK", and that it was committed to determining a "fair settlement of the UK's rights and obligations" [41] in Britain's withdrawal from the EU. They also promised to pass a Great Repeal Bill to convert EU law into UK law; however, none of their Brexit manifesto statements could be fulfilled under the current circumstances, particularly their statement that "no deal is better than a bad deal for the UK". Although the main reason for their election defeat in 2017 was due to Theresa May's dementia tax scandal, the Conservative Party could not instil confidence in the British people concerning a stable government that would lead the UK into beneficial Brexit negotiations. Even in the latter part of the Brexit negotiations in 2019, the Conservative Party and Prime Minister May were unable to solve problems (e.g., the Ireland border "backstop" issue) and only focused on inner-party politics rather than on providing solutions.

Figure 8 displays the results from the Facebook page of the Labour party, which supported remaining in the EU.

From the day of the referendum to the day of the vote, the Labour party focused on criticising the errors of the major Conservative Party rather than focusing on the Brexit negotiations. The Labour Party criticised the cabinets of both Cameron and May, worker's rights, housing policy, education policy, pension policy, and public health policy (including the NHS). These statements continually appealed to the public, insinuating that the Labour party was another option over the Conservatives. However, they did not state any clear policy on the Brexit negotiations; instead, they only criticised the 
Conservatives by countering Prime Minister May. The Labour party only focused on gaining control of Parliament and was not interested in the Brexit negotiations, and it was instead focused on Britain's national interests. In their manifesto of the 2017 general election, the Labour Party promised upon Brexit to scrap the Brexit white paper and to replace it with a fresh set of negotiating priorities with an "emphasis on the single market and customs union". With this, they were offering to immediately guarantee the rights of EU citizens living in Britain and to replace the "Great Repeal Bill" with an EU rights and protections bill that would ensure no change to workers' rights or environmental protections. Also, the Labour Party promised to reject a "no deal" with the European Union as a viable option. Overall, this research finds that, among the three major political parties, the Labour Party has been the most loyal to their manifesto in this case. The main criticism of the Labour Party has been that opposition leader Corbyn has not shown a clear stance on Brexit.

The main camp in favour of Brexit has been the UKIP; both the Conservatives and the Labour parties have maintained their policies to remain in the EU (except for some of the hard Brexiters in the Conservative party). The UKIP was the most important influence on the British public regarding the Brexit issue. It is therefore important to examine the results of the UKIP Facebook page in order to understand the results of the Brexit vote, presented in Figure 9.

As shown in Figure 9, Brexit can be seen as a large block, and the contents within this block can be understood as appeals to public emotions (as opposed to policies). The unique characteristic of the UKIP results is that they were focused on fishery rights, border control, and the fundamental idea of Brexit as Article 50 of the Lisbon Treaty. Overall, the UKIP did not provide a specific alternative but, rather, leaned on the emotional appeal of Euroscepticism to influence the Brexit vote. In their 2017 general election manifesto, the UKIP promised the following: to quit the jurisdiction of the European Court of Justice, to form the EU single market and customs union, to restore "full maritime sovereignty", to pay neither "divorce" money to the EU nor to contribute to the EU budget, and to complete the Brexit process by the end of 2019. At present, none of these promises have been fulfilled, and some of these promises contained false information. As such, the UKIP lost the election in a catastrophic manner. They still maintain Hard Brexit in their political stance; however, they do not have the same level of public support today as they did on referendum day because they have broken too many past promises.

\section{Discussion}

In the two years following the Brexit referendum, the following framing structures were used by the major British political parties and the UKIP on their official Facebook pages: (1) the Conservatives have maintained that they are focusing on British national interests in the Brexit negotiations; however, the realistic possibility of achieving their aims remains unclear; (2) the Labour Party has continuously claimed that they are the superior alternative to the Conservatives in the Brexit negotiations process; and (3) the UKIP has only focused on emotional nationalism (i.e., that Britain needs to leave the EU due to the fact of Euroscepticism). At the beginning of this study, we expected the results would be different from these parties' messages before the referendum. However, the results show that these parties' communicative framings have not changed during the period of post-referendum negotiations between the UK and the EU. These results imply that these parties' main concern was about gaining their political legitimacy and public support. Before the referendum, the Conservatives and the UKIP were the main contenders of the Leave movement by amplifying public fear regarding multiple crises (e.g., economic loss of EU membership or migrant crisis coming out of EU membership). The Labour was uncertain about the UK staying in the EU [42]. After the referendum, the Conservatives and the UKIP have continuously sought public support for Brexit by emphasising its benefits to the UK public. The Labour has criticised the misconducts of the Conservatives and the UKIP for gaining public support. Furthermore, Jeremy Corbyn, the leader of the Labour Party, called for a second referendum and intended to scrap the Conservatives' Brexit plan in order to regain its power [43]. 
The framing structures embedded in these parties' Facebook postings during the post-referendum period imply that their propagations could have misled the British public and created the political phenomenon of confusion surrounding Brexit. Zartaloudis [44] pointed out the political parties misled the British public in explaining what Brexit means and its further implications. Zartaloudis [44] (paragraph 8) subsequently pointed out that a "post-referendum agenda should not be driven by political chameleons that do not have a clear and consistent agenda based on facts and evidence". Unfortunately, the results indicate that the political parties could not correctly provide clear and plausible visions to the general public. Instead, they continuously exploit the British public's fear or uncertainty generated by Brexit. These unclear framing structures from the political parties' messages may increase further confusion among the British public. Every confirmation or denial of a frame publicly vitalises and strengthens the frame as reality [45]. Repetition of this process makes the frame seem like common sense, leading individuals not to question its validity. Instead, they will believe it is real, even unconsciously [45]. The British public has undergone this cognitive process, making it difficult for them to extricate themselves from the misleading information provided on Brexit. Hence, the British public would not be able to overcome their national task.

This misleading information illustrates the development process of the "heart of Europe" metaphor, in which British political parties have painted the metaphor of the EU as being irredeemably diseased, dead, non-existent, or rotten, which accelerated the Brexit misinterpretation [46]. Before this misinterpretation, the British people held negative sentiments towards the 'leave' camp's framing. According to the YouGov's report on this theme, respondents were asked to rank 'remain,' 'no deal,' and 'deal' in order of preference [46]. The public overwhelmingly chooses the 'remain' option (600) while a minimal number preferred 'no deal' (2) or 'deal' (30) [47].

\section{Conclusions}

In conclusion, this research used an automated computer-assisted semantic network analysis to investigate how the three major British political parties communicated with the public through Facebook from the date of the Brexit referendum to that of Brexit deal. The framing they showed to the public developed 'the heart of Europe' conceptual metaphor in a negative way, causing the public to express a strong opposing opinion on Brexit; however, despite divided public opinion and societal conditions, Britain leaving the EU became an established public fact.

In order to overcome the conflicts regarding framing, this study suggests enhancing collective intelligence [48]. The term "collective intelligence" was first used by American entomologist Wheeler in the 1911 book Ants: Their Structure, Development, and Behaviour [49]. Wheeler created a large ant house and discovered that individual ants cluster and form a high-intelligence system [49]. Wheeler's terminology has been applied extensively to the field of human sociology. Lévy, for example, defined the notion of collective intelligence in cyberspace as intelligence that is distributed everywhere, continuously valued, adjusted in real-time, and reaches actual mobilisation of competence [50]. Further, Jenkins [48] stated that collective intelligence helps the public to achieve participative democracy; in other words, collective intelligence allows the public to become active participants in the formation process of political discourse rather than simple receivers. This allows the public to fact check or be critical when accepting new information, though this information exchange system must be constructed between the elite class and the public in a political society.

This point also addresses Entman's cascading activation model, which is restrictively operating in the case of the UK (i.e., top-down framing cascading is working properly, whereas bottom-up feedback cascading is not working properly). Examining the Brexit case, it appears that, regrettably, the UK's three major political parties have been negligent in their efforts to share accurate information about their counterparts. If the UK had a sound, collective, intelligent system among its public, the political parties would not have disseminated inappropriate information to their voters. The Brexit case shows that the British political parties are likely to be under the yoke of their profits rather than the common good of the UK. 
This study used framing theory as its methodology, and it considered how the unexpected result of Brexit happened and identified which aspects of the referendum accepted by the voters were promoted by the major parties. Additionally, this study examined the reasons why the promises of the parties could not be fulfilled, causing the current confusion and political failures in British politics. The results showed that the "remain" campaigners, or the Conservative and Labour parties, did not provide a clear vision or explain the positive impact of remaining in the EU. Furthermore, the "leave" campaigners, or the UKIP, made three key promises that they could not realistically deliver or fulfil. This ultimately resulted in false information being provided to the public that constructed untrue framing and influenced voters to make a decision that likely went against their best interests. In the two years since the 2016 referendum, none of the major British political parties or leave campaign politicians have provided reliable solutions or accurate information to the British public regarding the underlying truth of the Brexit referendum vote. Such inaccuracy might defect the sustainable social media communication and interaction between the political parties and the general public in the UK. Once again, the importance of accurate information and media fact checking within this modern, cyber-saturated, political society is demonstrated. Perhaps, there should be a certain amount of time established by which politicians can influence (or deceive) voters in their framing via information aimed at swaying results to their desired outcome. This is important since an unchecked system in this regard can negatively affect entire societies, as seen in the two years of Brexit confusion that has spread across all aspects of British society. Now, almost three years have passed since the referendum, and we still do not know how Brexit will end-it is unclear what the UK-EU negotiations will look like or if there will be "No Deal". All of this Brexit chaos serves as a tremendous paradoxical example of political failure in British political history.

Author Contributions: Conceptualization, Y.K.; Methodology and Software, S.W.C.; Validation, S.W.C. and Y.K.; Formal Analysis, S.W.C.; Investigation, S.W.C.; Resources, S.W.C. and Y.K.; Data Curation, S.W.C. and Y.K.; Writing-Original Draft Preparation, S.W.C. and Y.K.; Writing-Review and Editing, S.W.C. and Y.M.K; Visualization, S.W.C.; Supervision, Y.K.; Project Administration, S.W.C. and Y.K.

Funding: This research received no external funding.

Acknowledgments: This paper was supported by the Korea University Grant (2019) and by the KU Research Professor Program at Konkuk University.

Conflicts of Interest: The authors declare no conflict of interest.

\section{References}

1. Llwellyn, C.; Cram, L. The Results Are in and the UK Will \#Brexit: What Did Social Media Tell Us about the UK's EU Referendum? EU Referendum Analysis 2016: Media, Voters and the Campaign. Available online: http://www.referendumanalysis.eu/ (accessed on 10 January 2019).

2. Office for National Statistics. Internet Access-Households and Individuals, Great Britain: ONS. 7 August 2018. Available online: https://www.ons.gov.uk/peoplepopulationandcommunity/householdcharacteristics/ homeinternetandsocialmediausage/bulletins/internetaccesshouseholdsandindividuals/2018 (accessed on 10 January 2019).

3. We Are Social, Global Digital Report 2018. Available online: https://digitalreport.wearesocial.com/ (accessed on 8 August 2019).

4. Bale, T. Who leads and who follows? The symbiotic relationship between UKIP and the Conservatives-and populism and Euroscepticism. Politics 2018, 38, 263-277. [CrossRef]

5. Kim, Y.; Hong, J. The Rise of Euroscepticism and Internal Nationalism in the Westminster Democracy-The Questions of the 2015 British Parliamentary Election. Korean J. Br. Stud. 2015, 33, 197-233. Available online: https://www.kci.go.kr/kciportal/ci/sereArticleSearch/ciSereArtiView.kci? sereArticleSearchBean.artiId=ART002008268 (accessed on 8 August 2019).

6. Travis, A. The Leave Campaign Made Three Key Promises-Are They Keeping Them? The Guardian, 27 June 2016. Available online: https:/www.theguardian.com/politics/2016/jun/27/eu-referendum-reality-checkleave-campaign-promises (accessed on 10 January 2019). 
7. Full Fact, UK's EU Membership Fees. Available online: https://fullfact.org/europe/our-eu-membership-fee55-million/ (accessed on 26 August 2019).

8. Johnson, B. The Only Way to Take Back Control of Immigration Is to Vote Leave. Vote Leave Take Control. 23 June 2016. Available online: http://www.voteleavetakecontrol.org/boris_johnson_the_only_way_to_take_ back_control_of_immigration_is_to_vote_leave_on_23_june.html (accessed on 10 January 2019).

9. Ammerman, P. The Effectiveness of UKIP Campaign Advertising. Navigator, 26 June 2016. Available online: http://www.navigator-consulting.com/articles/the-effectiveness-of-ukip-campaign-advertising/74 (accessed on 26 August 2019).

10. Portes, J. Immigration, Free Movement and the EU Referendum. Natl. Inst. Econ. Rev. 2016, $236,14-22$. [CrossRef]

11. Allen, N. 'Brexit Means Brexit': Theresa May and Post-Referendum British Politics. Br. Politics 2018, 13, 105-120. [CrossRef]

12. Copus, C. The Brexit Referendum: Testing the Support of Elites and their Allies for Democracy; Or, Racists, Bigots and Xenophobes, Oh My! Br. Politics 2018, 13, 90-104. [CrossRef]

13. Clarke, H.; Goodwin, M.; Whiteley, P. Brexit: Why Britain Voted to Leave the European Union; Cambridge University Press: Cambridge, UK, 2017.

14. Marsh, D. Brexit and the Politics of Truth. Br. Politics 2018, 13, 79-89. [CrossRef]

15. Watson, M. Brexit, the Left Behind and the Let Down: The Political Abstraction of 'The Economy' and the UK's EU Referendum. Br. Politics 2018, 13, 17-30. [CrossRef]

16. Crafts, N. The Growth Effects of EU Membership for the UK: A Review of the Evidence. Social Market Foundation Global Perspectives Series Paper 7. 2016. Available online: http://www.smf.co.uk/wp-content/uploads/2016/04/SMF-CAGE-The-Growth-Effects-of-EU-Membershipfor-the-UK-a-Review-of-the-Evidence-.pdf (accessed on 1 April 2019).

17. Dhingra, S.; Sampson, T. "Life after Brexit: What Are the UK's Options Outside the European Union?". CEP Brexit Analysis No. 1. 2016. Available online: http://cep.lse.ac.uk/pubs/download/brexit01.pdf (accessed on 1 April 2019).

18. Dhingra, S.; Ottaviano, G.; Sampson, T.; Van Reenen, J. The Impact of Brexit on Foreign Investment in the UK. CEP Brexit Analysis No. 3. 2016. Available online: https://cep.lse.ac.uk/pubs/download/brexit03.pdf (accessed on 1 April 2019).

19. Sampson, T. Brexit: The Economics of International Disintegration. J. Econ. Perspect. 2017, 31, $163-184$. [CrossRef]

20. Gudgin, G.; Coutts, K.; Gibson, K.; Buchanan, J. The Role of Gravity Models in Estimating the Economic Impact of Brexit; Working Paper No. 490; Centre for Business Research, University of Cambridge: Cambridge, MA, USA, 2017. Available online: http://www.cbr.cam.ac.uk/fileadmin/user_upload/centre-for-business-research/ downloads/working-papers/wp490.pdf (accessed on 27 August 2019).

21. Coutts, K.; Gudgin, G.; Buchanan, J. How the Economic Profession Got It Wrong on Brexit; Centre for Business Research, University of Cambridge Working Paper No. 493; Springer: Berlin/Heidelberg, Germany, 2018. Available online: http://www.cbr.cam.ac.uk/fileadmin/user_upload/centre-for-business-research/downloads/ working-papers/wp493.pdf (accessed on 27 August 2019).

22. Jackson, D.; Thorsen, E.; Wring, D. EU Referendum Analysis 2016: Media, Voters and the Campaign. 2016. Available online: http://www.referendumanalysis.eu/ (accessed on 8 August 2019).

23. Usherwood, S.; Wright, K. Talking Past Each Other: The Twitter Campaigns. EU Referendum Analysis 2016: Media, Voters and the Campaign. 2016. Available online: http://www.referendumanalysis.eu/eu-referendum-analysis-2016/section-7-social-media/talkingpast-each-other-the-twitter-campaigns/ (accessed on 1 April 2019).

24. Mullen, A. Leave Versus Remain: The Digital Battle. EU Referendum Analysis 2016: Media, Voters and the Campaign. 2016. Available online: http://www.referendumanalysis.eu/eu-referendum-analysis-2016/ section-7-social-media/leave-versus-remain-the-digital-battle/ (accessed on 1 April 2019).

25. Vasilopoulou, S. Campaign Frames in the Brexit Referendum. EU Referendum Analysis 2016: Media, Voters and the Campaign. 2016. Available online: http://www.referendumanalysis.eu/eu-referendum-analysis2016/section-8-voters/campaign-frames-in-the-brexit-referendum/ (accessed on 1 April 2019).

26. Khabaz, D. Framing Brexit: The Roe, and the Impact, of the National Newspapers on the EU referendum. Newsp. Res. J. 2018, 39, 496-508. [CrossRef] 
27. Goffman, E. Frame Analysis: An Essay on the Organization of Experience; Harper and Row: New York, NY, USA, 1974.

28. Gitlin, T. The Whole World Is Watching: Mass Media in the Making and Unmaking of the New Left; University of California Press: Oakland, CA, USA, 1980.

29. Fiske, S.; Taylor, S. Social Cognition, 2nd ed.; McGraw-Hill: New York, NY, USA, 1991.

30. Entman, R. Framing: Toward Clarification of a Fractured Paradigm. J. Commun. 1993, 43, 51-58. [CrossRef]

31. Scheufele, D. Framing as a Theory of Media Effects. J. Commun. 1999, 49, 103-122. [CrossRef]

32. Entman, R. Cascading Activation: Contesting the White House's Frame After 9/11. Political Commun. 2003, 20, 415-432. [CrossRef]

33. Matthes, J.; Kohring, M. The Content Analysis of Media Frames: Toward Improving Reliability and Validity. J. Commun. 2008, 58, 258-279. [CrossRef]

34. Van Attelveldt, W. Semantic Network Analysis: Techniques for Extracting, Representing and Querying Media Content; BookSurge Publishing: North Charleston, SC, USA, 2008.

35. Schultz, F.; Kleinnijenjuis, J.; Oegema, D.; Utz, S.; van Atteveldt, W. Strategic Framing in the BP Crisis: A Semantic Network Analysis of Associated Frames. Public Relat. Rev. 2012, 38, 97-107. [CrossRef]

36. Jiang, G.; Evans, J.; Endle, C.M.; Solbrig, H.R.; Chute, C.G. Using Semantic Web Technologies for the Generation of Domain-Specific Templates to Support Clinical Study Metadata Standards. J. Biomed. Semant. 2016, 7, 3710-3736. [CrossRef] [PubMed]

37. Kim, L.; Kim, N. Connecting Opinion, Belief and Value: Semantic Network Analysis of a UK Public Survey on Embryonic Stem Cell Research. J. Sci. Commun. 2015, 14, 1-23. [CrossRef]

38. Yoon, S.; Chung, S. Promoting a World Heritage Site through Social Media: Suwon City's Facebook Promotion Strategy on Hwaseong Fortress (in South Korea). Sustainability 2018, 10, 2189. [CrossRef]

39. Yoon, S.; Chung, S. Semantic Network Analysis of Legacy News Media Perception in South Korea: The Case of PyeongChang 2018. Sustainability 2018, 10, 4027. [CrossRef]

40. Social Media Research Foundation, NodeXL, Features. Available online: https://www.smrfoundation.org/ nodexl/features/ (accessed on 10 September 2019).

41. The Conservatives, Forward Together: The Conservative Manifesto. Available online: https://www. conservatives.com/manifesto (accessed on 26 August 2019).

42. Mason, R. Labour Voters in the Dark about Party's Stance on Brexit, Research says. The Guardian, 30 May 2016. Available online: https://www.theguardian.com/politics/2016/may/30/labour-voters-in-the-dark-aboutpartys-stance-on-brexit-research-says (accessed on 26 August 2019).

43. The Labour, Accessible Manifesto, Negotiating Brexit. Available online: https://labour.org.uk/manifesto/ negotiating-brexit/ (accessed on 26 August 2019).

44. Zartaloudis, S. From U-Turn to U-Turn: Did Pro-Brexit Politicians Mislead the British Public? The University of Birmingham, Perspectives. Available online: https://www.birmingham.ac.uk/research/perspective/brexiteu-nationals.aspx (accessed on 27 August 2019).

45. Lakoff, G.; Wehling, E. Your Brain's Politics: How the Science of Mind Explains the Political Divide; Andrews: Exeter, UK, 2016.

46. Musolff, A. How metaphors can shape political reality: the figurative scenarios at the heart of Brexit. Pap. Lang. Commun. Stud. 2017, 1, 2-16. Available online: https://www.uea.ac.uk/documents/241631/16651997/pmus/ 5b49c7fe-c73d-4905-86e4-6bf3e6dab278 (accessed on 17 September 2019).

47. YouGov. May's Brexit Deal Leads in Just Two Constituencies as It Suffers from Being Everyone's Second Choice. YouGov, 6 December 2018. Available online: https:/yougov.co.uk/topics/politics/articles-reports/ 2018/12/06/mays-brexit-deal-leads-just-two-constituencies-it- (accessed on 10 January 2019).

48. Jenkins, H. Convergence Culture: Where Old and New Media Collide; New York University Press: New York, NY, USA, 2006.

49. Wheeler, M. The Ant-Colony as an Organism. J. Morphol. 1911, 22, 301-325. [CrossRef]

50. Lévy, P. Collective Intelligence: Mankind's Emerging World in Cyberspace; Bononno, R., Ed.; Plenum Trade: New York, NY, USA, 1997. 